\title{
POST-FIRE SOIL EROSION MITIGATION: A REVIEW OF THE LAST RESEARCH AND TECHNIQUES DEVELOPED IN PORTUGAL
}

\author{
S. PRATS*, M. MALVAR, M.A.S. MARTINS, J.J. KEIZER \\ CESAM - Centro de Estudos do Ambiente e do Mar \& Departamento de Ambiente e Ordenamento. \\ Universidade de Aveiro. 3810-Aveiro, Portugal.
}

\begin{abstract}
Post-fire soil erosion risk assessment is not exempt of uncertainties. In many parts of the world post-fire soil erosion can have devastating effects over forest ecosystems, infrastructures and human life. However, in the Mediterranean countries, it has been defined as "low" and it was attributed to a long history of intense land use. This review paper integrates the last research assessing post-fire runoff and soil erosion as well as mitigation techniques focussing in Portugal. In the case of north-central Portugal, recent research assessing wildfire and ground preparation effects leads to the conclusion that post-fire soil losses was as high as 5-10 Mg ha-1yr-1, while ground preparations soil losses doubled these figures. Since those values are higher than the estimates for tolerable soil losses, further considerations must be taken in order to guarantee a sustainable land use. The advantages of post-fire soil erosion control with straw mulching are well known worldwide. Recently, other treatments were assessed in recently burnt eucalypt and pine plantations in Portugal: 1) the eucalypt chopped bark mulch;2) the slash logging mulch (unchopped twigs, stems and leaves); 3) the hydromulch, a mixture of water, organic fibres, seeds, nutrients and a surfactant with good performance in cut slopes rehabilitation; and 4) the polyacrylamides (PAM), a chemical agent with good performance in agricultural soil erosion control and high potential due to its low application rate. The more effective treatments were those increasing the ground cover, one of the most important key factors for soil erosion. For this reason, the eucalypt chopped bark mulch and the hydromulch reduced the runoff in 50\% and the soil erosion in 80-90\%, while the PAM did not achieved the required reduction effect. In areas where the ground cover was high (due to the presence of a needle carpet) the slash logging mulch was not effective since soil erosion was already low in the untreated areas.
\end{abstract}

Mitigación del riesgo de erosión post-incendio: revisando los últimos avances y técnicas desarrolladas en Portugal

RESUMEN. Existe una gran incertidumbre en la cuantificación del riesgo erosivo tras un incendio forestal. En algunas partes del mundo la erosión post-incendio 
puede tener efectos devastadores sobre los ecosistemas forestales, las infraestructuras y también sobre las vidas humanas. Sin embargo, en los países del litoral mediterráneo la erosión post-incendio suele ser catalogada como "baja", especialmente debido a una larga historia de intenso uso del suelo. Este trabajo de revisión integra los últimos estudios realizados en Portugal sobre la evaluación del riesgo de erosión y de escorrentía post-incendio así como las técnicas para su mitigación. En el caso del centro-norte de Portugal, estudios recientes han demostrado que los incendios forestales pueden resultar en pérdidas elevadas (5-10 Mg ha ${ }^{1}$ año $\left.{ }^{-1}\right)$, mientras que algunas actividades de preparación del suelo que se llevan a cabo en la región pueden duplicar estos valores. Todas estas figuras sobrepasan las estimativas de pérdidas de suelo tolerables, por lo que se deben tomar medidas que garanticen la sostenibilidad de los usos del suelo. A nivel mundial, se ha constatado que el mulch de paja es el método más efectivo para reducir la erosión del suelo tras un incendio de alta severidad. Recientemente, otros tratamientos han sido testados en eucaliptales y pinares incendiados de Portugal: 1) el mulch de cortezas de eucalipto trituradas; 2) el de restos forestales no triturados (ramas, palos, hojas); 3) el hydromulch, una variante del mulch compuesto por agua, fibras orgánicas, surfactantes, nutrientes y semillas utilizado en la restauración de taludes y canteras; $y$ 4) las poliacrilamidas (PAM), un agente químico utilizado con éxito en la reducción de la erosión en terrenos agrícolas y con alto potencial debido a su baja tasa de aplicación. Los tratamientos más efectivos fueron aquellos que afectaron al factor determinante de la erosión: la cubierta del suelo. Por esta razón el mulch de cortezas de eucalipto trituradas y el hydromulch redujeron la escorrentía a la mitad, y la erosión en un 80-90\%, mientras que las poliacrilamidas no tuvieron ningún efecto. Los restos forestales no triturados aplicados en incendios con alguna cubierta sobre el suelo (agujas de pino) no fueron efectivos debido al bajo riesgo erosivo de esas áreas.

Key words: wildfires, soil erosion, runoff, mulch, effectiveness.

Palabras clave: incendios forestales, erosión del suelo, escorrentía, mulch, efectividad.

Received 13 November 2013 Accepted 20 February 2014

*Corresponding author: CESAM - Centro de Estudos do Ambiente e do Mar \& Departamento de Ambiente e Ordenamento. Universidade de Aveiro. 3810-Aveiro, Portugal. E-mail: sergio.prats.alegre@gmail.com

\section{Introduction}

Once post-fire soil erosion risk has been determined, the second step is to implement mitigation techniques of proven effectiveness. Mulching consist in the application of an organic cover placed over the soil. Mulch protects the soil from the kinetic energy of raindrops and decreases the sheer force of runoff to detach and transport the soil particles (Bautista, 2009). Despite to be a well-known post-fire soil erosion mitigation treatment 
in the USA, in the Iberian Peninsula, the use of straw mulch have rarely been employed so far (e.g. Bautista et al., 1996; Badía and Martí, 2000; Fernández et al., 2011). In the case of Portugal, once straw availability is lacking in many parts of the country, the first field trial on the effectiveness of post-fire soil conservation measures was based on the application of heavy loads of eucalypt logging litter (Shakesby et al., 1996). They demonstrated that these forest residues were highly effective for reducing soil erosion in burnt eucalypt as well as maritime pine plantations, but surprisingly, they received very little public attention. Despite to be somewhat unconventional, the former study was pioneer in using forest residue-derived mulches for reducing post-fire soil erosion. The study remained long time without follow up, but in recent years new studies have continued with this research line (Prats et al., 2012, 2014). Despite the high surface burnt each year in Portugal (Fig. 1), post-fire soil erosion mitigation treatments have been rarely applied, although this may be changing with the emergency stabilization measures funded by PRODER (under sub-Action 2.3.2.1) for selected, 2010-burnt areas.

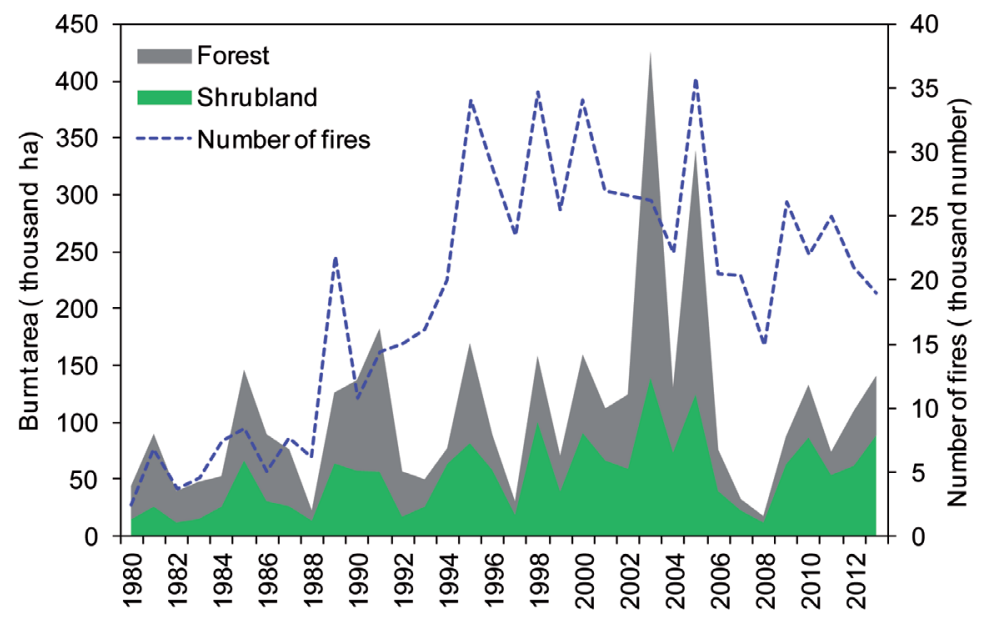

Figure 1. Number of wildfires and burnt area in Portugal from 1980 to 2013 (ICFN, 2014).

The main aims of this work were 1) to summarize from the literature the risk of soil erosion after wildfires under different forest management scenarios in central Portugal, 2) to contribute to a better knowledge of the effectiveness of the newest post-fire soil erosion mitigation treatments compared to the classical and effective straw mulch, 3) to compare its costs and analyze the suitability of applying these treatments to reduce post-fire soil erosion.

\section{Forest formations in Central Portugal}

Since the Neolithic age, fire has been used as a source of energy and as a tool in defence, for hunting and for managing the landscape, introducing agricultural and pasture lands in previously forested areas (Bird et al., 2008). As a result, forests had lower fuel loads and became intersected by open spaces, whilst fires became more frequent and, at 
the same time, of lower intensity (Pausas, 2004). In the case of Portugal, the landscape reflects a long history of intense land use and management, with a mosaic of (semi-) natural and man-made agricultural and afforested lands, unploughed and ploughed hillslopes connected by a dense net of tracks and roads (Shakesby, 2011). Since the 1980's, however, wildfires have increased dramatically in frequency and extent, aided by a general warming and drying trend but driven primarily by socio-economic changes (Ferreira et al., 2008). These changes were first and foremost the large-scale introduction of commercial plantations of fire-prone tree species such as eucalypt and pine (Fig. 2 ), and the decline in traditional practices like grazing and coppicing, increasing the accumulation of flammable materials (Radich and Alves, 2000; Shakesby et al., 1996). Following the Instituto da Conservação da Natureza e das Florestas - Ministério da Agricultura, Mar, Ambiente e Ordenamento do Território (ICNF-MAMAOT, 2013), the total forested area in Portugal was $35.4 \%$ in 2010, very similar to the European average $(38 \%)$. However, an exotic tree, Eucalyptus globulus rose as the first forest specie (812 000 ha), followed by Pinus pinaster (741 000 ha) and Quercus suber (737 000 ha). The eucalypts are typically planted as monocultures for paper pulp production. The harvesting cycles are about every 7-14 years, after which the stumps are left to regrow up to four times and a new plantation cycle begins, which sometimes involve land preparations operations such as rip-ploughing and terracing (Shakesby et al., 1994; Ferreira et al., 1997; Leighton-Boyce et al., 2007; Malvar et al., 2011, 2013).
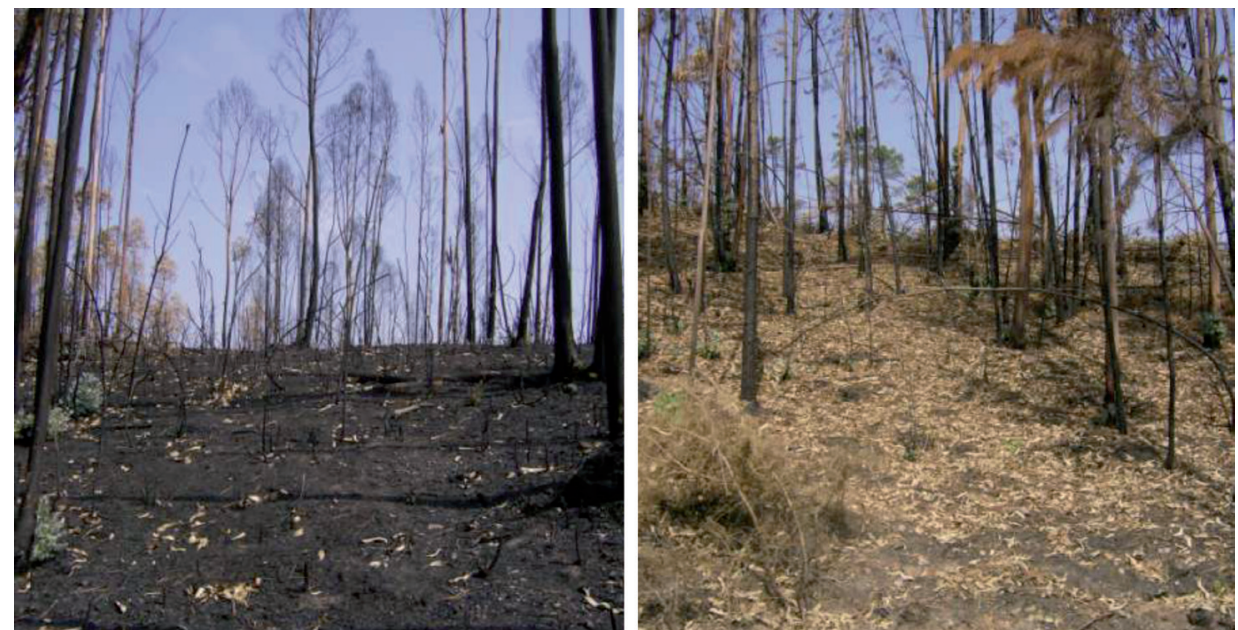

Figure 2. In the Pessegueiro wildfire of 2007, the tree canopies were fully consumed at the eucalypt study site (left) but only partially at the pine study site (right), so that the lower fire severity was associated to "natural" mulching by the subsequent cast of the scorched leaves and needles.

\section{Wildfires effects and post-fire soil erosion}

The most evident change produced by a wildfire is the total or partial loss of the vegetation and litter cover. The removal of vegetation and litter reduces rainfall interception and, thereby, enhances throughfall (Soto et al., 1998) and can increase overland flow (Soto 
et al., 1993) as well as subsurface and groundwater flow (Lavabre et al., 1993). Vegetation loss also decreases the leaf area from which evapotranspiration occurs, and reduces the obstacles to overland flow (Shakesby and Doerr, 2006). Besides vegetation and litter cover, wildfires can have significant impacts on soil chemical and physical properties, depending to a large extent on fire severity (e.g. Inbar et al., 1998; Robichaud, 2000; Shakesby and Doerr, 2006). Fire has been found to cause (partial) combustion of organic matter, deterioration of soil structure and aggregate stability, increase in bulk density and soil water repellency (Giovannini et al., 1988; Imeson et al., 1992; DeBano, 2000; Doerr et al., 2000; Fernández et al., 2004; Fox et al., 2007; Llovet et al., 2009). These changes often make the soil more susceptible to overland flow generation and removal by rain drop and runoff (Shakesby, 2011). Fire-induced changes in soil water repellency deserve special reference in the case of northcentral Portugal. The prevalent forest plantations of Maritime Pine and especially eucalypt commonly exhibit pronounced repellency (Doerr et al., 1996; Ferreira et al., 1997; LeightonBoyce et al., 2007; Keizer et al., 2008; Malvar et al., 2011) and on the other hand, soil water repellency is widely considered as one of the main factors in enhancing runoff generation and the associated soil losses following wildfire (e.g. Shakesby and Doerr, 2006; Leighton-Boyce et al., 2007; Sheridan et al., 2007).

In a nutshell, post-fire soil erosion is a two-stage process, involving detachment of soil particles and their subsequent transport by water, wind or gravity (Morgan 2005), that is driven primarily by fire severity (Prosser and Williams, 1998; Robichaud, 2000; Benavides-Solorio and MacDonald, 2005; González-Pelayo, 2006). However, fire severity cannot be measured directly, it must be assessed after "the smoke has gone", using indirect indicators that give qualitative rather than quantitative estimates of the temperature. Ryan and Noste (1985) developed a fire severity index based on visual estimation of soil cover by litter and duff, and of alteration of soil colour. Vega et al. (2008) used indicators such as canopy cover consumption, litter cover and ash colour (Fig. 3). Other severity indices such as the Twig Method Severity Index (TMSI; Moreno and Oechel, 1989) and the NIR-based Maximum Temperature Reached (Guerrero et al., 2007; Maia et al., 2012) can be more precise but also more labour-intensive.
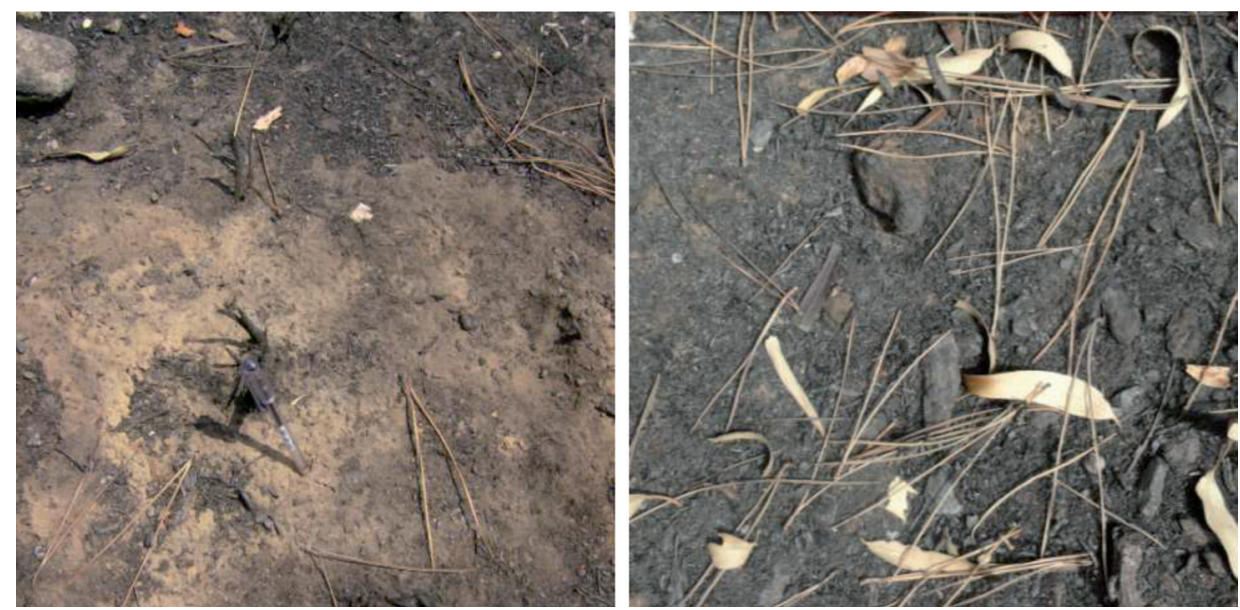

Figure 3. Ash colour indicating higher burnt severity on the left than on the right photograph. 
Extreme sediment losses of 20 to even $170 \mathrm{Mg} \mathrm{ha}^{-1}$ year $^{-1}$ have been observed following high severity wildfires in North America (Robichaud et al., 2000; Spigel and Robichaud, 2007; Riechers et al., 2008) as well as in Europe, (Spain, France, Greece and Portugal; as it was recently reviewed by Shakesby, 2011). Since the 1980's (Swanson, 1981), it is generally accepted that fire-enhanced erosion rates decrease with time-since-fire till they return to background levels at the end of the so-called window-of-disturbance (Shakesby and Doerr, 2006). This window-of-disturbance is estimated to last between 3 to 10 years, depending mainly on fire severity and post-fire climate conditions (e.g. DeBano et al., 1998; Andreu et al., 2001; Robichaud, 2009). The relation between wildfire and soil erosion, however, is far to be straightforward. Various authors have measured extreme soil losses still eight years after the wildfire (Robichaud et al., 2013b) and others have reported negligible soil erosion rates after wildfires (Kutiel and Inbar, 1993; Sheridan et al., 2007), which indicated that soil type, soil parent material or vegetation re-establishment can be also important factors. In general, in Mediterranean regions including Portugal, post-fire soil erosion rates tend to be low (Fig. 4). Perhaps more importantly, however, is the fact that there is much uncertainty in evaluating erosion rates as "tolerable" or not in terms of net soil loss, as the rate of soil formation continues to be poorly known. The existing estimates point to less than $1 \mathrm{Mg} \mathrm{ha}^{-1}$ year ${ }^{-1}$, with large variations between regions (Alexander 1988; Wakatsuki and Rasydin, 1992; Verheijen et al., 2009).

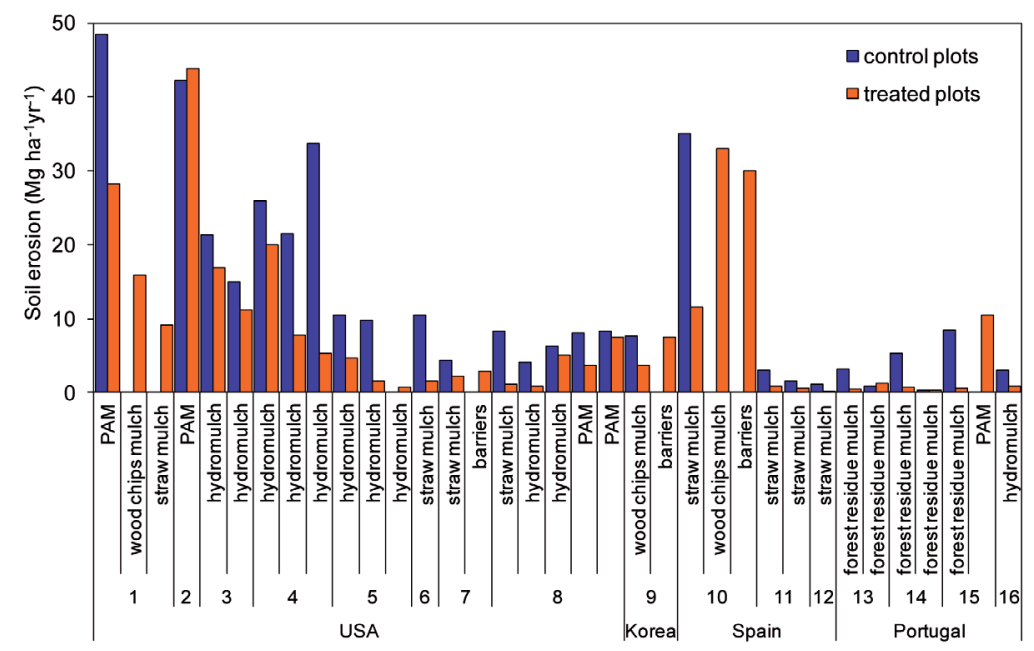

Figure 4. Post-fire soil erosion rates measured on control and mulched treated areas around the world. Treatments were grouped as: PAM (polyacrylamide-based dry or wet formulations ground or aerially applied), wood chip mulch (from in situ grinded trees or manufactured chips); straw mulch (straw alone or combined with seeds); hydromulch (aerial or ground application); barriers (log or shrub erosion barriers); forest residue mulch (logging slash or chopped bark mulches). Author abbreviations are: 1, Riechers et al. (2008); 2, Wohlgemuth and Robichaud (2007); 3, Wohlgemut et al. (2006); 4, Wohlgemut et al. (2010); 5, Hubbert et al. (2011); 6, Dean (2001); 7, Wagenbrenner et al. (2006); 8, Rough (2007); 9, Kim et al. (2008); 10, Fernández et al. (2011); 11, Badía and Martí (2000); 12, Bautista et al. (1996); 13, Shakesby et al. (1996); 14, Prats et al. (2012); 15, Prats et al. (2014); 16, Prats et al. (2013). 


\subsection{Post-fire runoff and soil erosion risk assessment in Portugal}

In Fig. 5 the annual figures of runoff coefficient and soil losses are depicted for each one of the untreated field plots monitored on six different sites during the first post-fire year in north-central Portugal (see also Table 1). Runoff coefficients ranged broadly, between 6 to $50 \%$, with a clear decreasing trend as plot size increased. The few studies that monitored the runoff during the first post-fire year in untreated eucalypt and pine plantations in central Portugal used $16 \mathrm{~m}^{2}$ plots (Shakesby et al., 1996), and exhibited runoff coefficients of $20 \%$. This figure was slightly lower than the Pessegueiro untreated eucalypt plots. However, these studies differed also in time-since fire and thus, surface cover. In the case of the pine plots, the lower runoff coefficient $(6 \%)$ was attributed to the low fire severity, as indicated by the higher needle cover over the soil (Fig. 2). Other researchers in Eastern Iberian Peninsula have also shown low runoff rates (Cerdà et al., 1995; Bautista et al., 1996; Cerdà and Doerr, 2007) but conditions such as the bigger plot sizes, different parent material and the more arid rainfall regime make the comparison of results difficult.
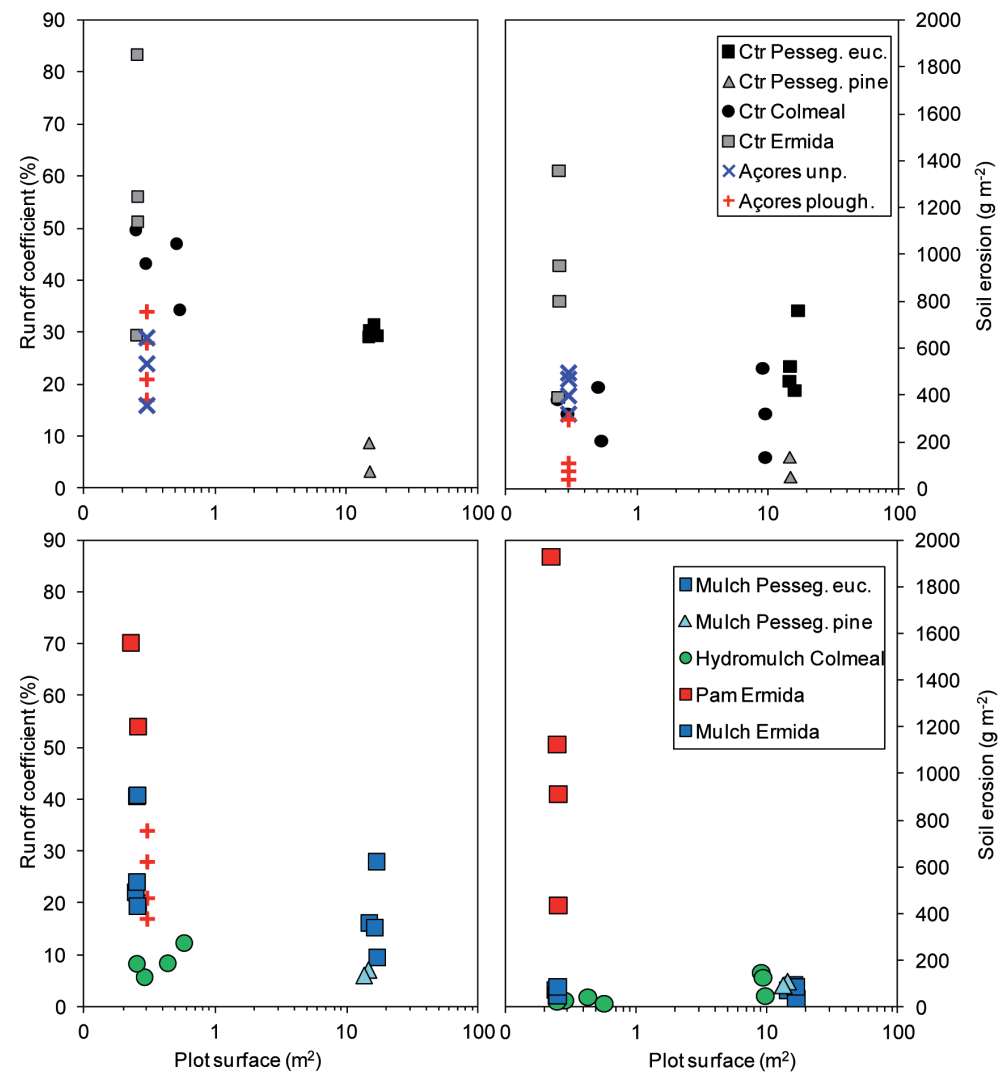

Figure 5. Runoff coefficient (left figures) and soil erosion (right figures) versus plot size measured during the first year after wildfire for the control (above) plots and the treated plots (below).

Data are from Prats et al. $(2012,2013,2014)$ and Malvar et al. (2013). 


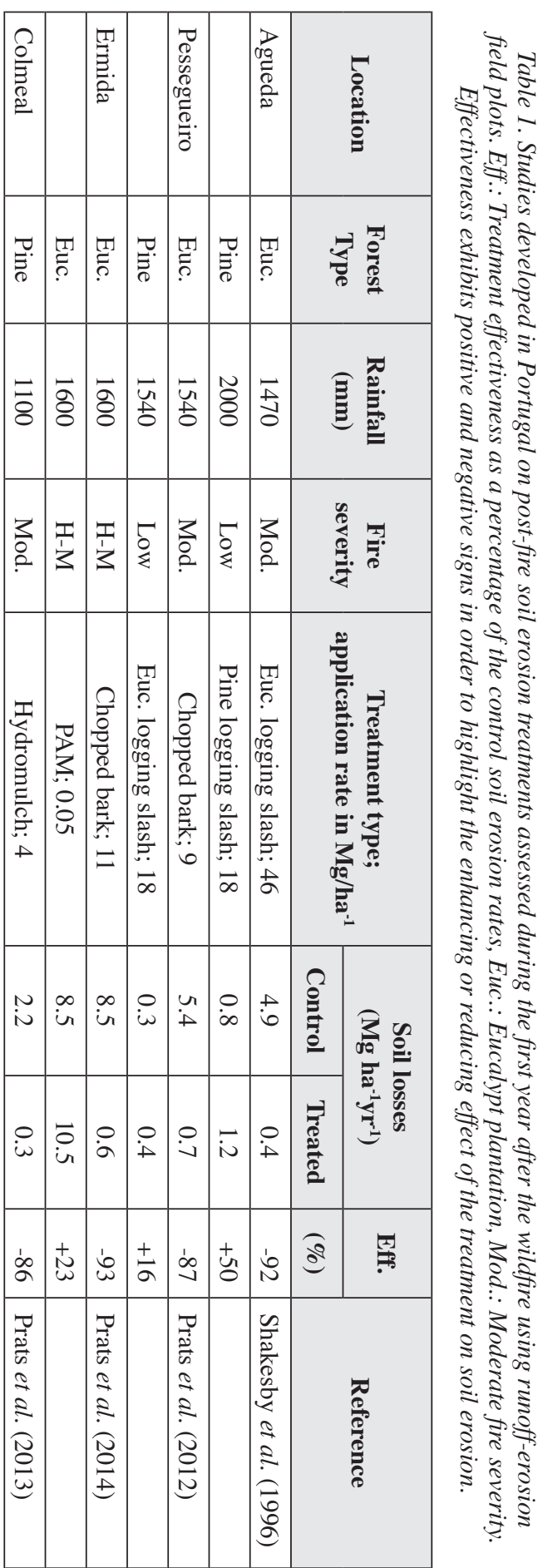


In the case of soil erosion, with exception of the Ermida site, the plot size seemed not to have a clear effect on the range of plots tested here, and the average erosion for the first year was, indistinctively, around $5 \mathrm{Mg} \mathrm{ha}^{-1}$. These figures are comparable with other Portuguese post-fire scenarios and other studies around the world (Fig. 4). The soil erosion on the untreated plots was low, especially when compared with the studies in North America and NW Iberian peninsula, but similar to the Mediterranean figures of Portugal and East Spain, except in the case of Ermida, which reported soil erosion rates as high as $10 \mathrm{Mg} \mathrm{ha}^{-1}$. The higher soil erosion rates measured in the Portuguese context can be linked to field indicators useful for land managers. Wildfires on slopes up to $20^{\circ}$, with less than $10 \%$ of litter and/or leaves covering the soil and complete canopy combustion (see Fig. 2) will result in soil erosion rates up to $5 \mathrm{Mg} \mathrm{ha}^{-1}$ during the first year after the fire. Furthermore, if the ashes colour is white, grey or red in more than $10 \%$ of the soil surface (see Fig. 3), the risk of soil erosion can rise as far as $10 \mathrm{Mg} \mathrm{ha}^{-1}$. The low erosion rates in the untreated Pessegueiro pine plots (Fig. 5; triangles) were attributed to lower fire severity, especially when compared to the Ermida site. But the low rates can also be attributed first and foremost to a long history of human landscape impact up to the present days (Shakesby, 2011). This was especially true in the case of the ploughed site of the Açores wildfire (Fig. 5; cross “+”" symbols). The ploughing effect on runoff was not important, but apparently it seemed to reduce the soil erosion. Further analysis carried out by Malvar (2013) led to think that instead to be considered as a soil conservation measure, the lower-than expected soil erosion rates could be related to soil exhaustion and formation of a stone lag, once the ploughing took place about 20 years before the wildfire. The soil erosion could firstly be enhanced immediately after ploughing (as referred to by Shakesby et al., 1994) and decreased several years later, once the soils became depleted and exhausted (Fig. 6). In fact, Martins et al. (2013) have measured median soil erosion rates as high as $12-36 \mathrm{Mg} \mathrm{ha}^{-1}$ during the first year after terracing in a recently burnt area.

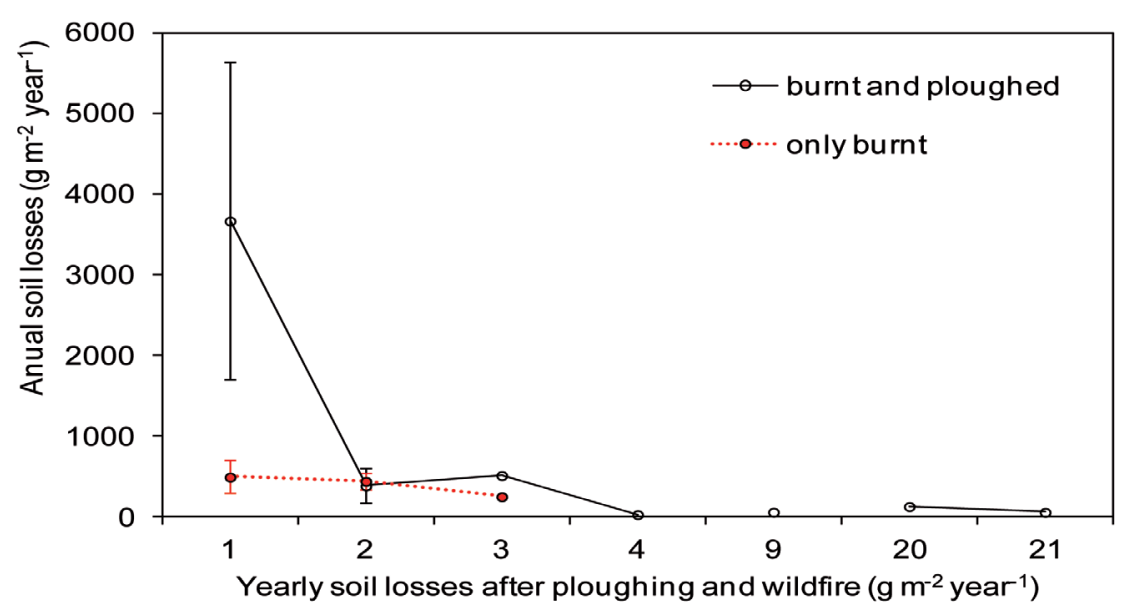

Figure 6. Annual soil losses measured in sites subjected to burnt and ploughing compared to only burnt. Error bars represents standard deviation from the median figure. Data are from Martins et al. (2013), Ferreira et al. (1997), Figueiredo et al. (2011), Shakesby et al. (1996), Shakesby et al. (1994), Prats et al. (2012, 2013, 2014) and Malvar et al. (2013). 
Some considerations can be derived about soil fertility when analyzing the organic matter percentage in the eroded sediments. This fraction, composed mostly of particulate pieces of charcoal and black ashes, was almost invariable around 50\% on all the Portuguese studies, and contained a substantial part of the nutrient stocks of the forest (Soto, 1993; Ferreira et al., 2008). Compared with other studies in Galicia (Soto and Diaz-Fierros, 1998) and North America (Spigel and Robichaud, 2007), the annual organic matter losses in Portugal were in the same range ( 1 to $\left.5 \mathrm{Mg} \mathrm{ha}^{-1}\right)$. However, the former authors reported soil erosion rates one order of magnitude higher (13 to $20 \mathrm{Mg} \mathrm{ha}^{-1}$ at slope scale plots up to $100 \mathrm{~m}^{2}$ ) than in the Portuguese studies (5 to $10 \mathrm{Mg} \mathrm{ha}^{-1}$ ). Shakesby (2011) summarized that "the post-fire nutrient losses in mono-specific plantations of pine and, particularly eucalypt on already degraded soils seem to be most at risk because post-fire nutrient depletion exacerbates an already considerable loss of nutrients caused by clear-felling and timber removal alone".

Recently, the ICNF soil erosion predictions for the Tavira wildfire, which destroyed a total of 24000 ha in the Algarve region (Catraia Technical Report; ICNF, 2013), ranged between less than 5 to more than $200 \mathrm{Mg} \mathrm{ha}^{-1} \mathrm{year}^{-1}$, which is much higher than the bulk of figures reported previously for Portugal and also on the extensive review of Shakesby (2011). Far to be optimistic, these results can lead to think that soil erosion already happened, and that the Portuguese soils started to get exhausted. It is necessary to consider that the funding for post-fire rehabilitation can be as high as several dozens of millions of dollars (\$5 millions in the Catraia 2012 wildfire; \$72 millions in the Cerro Grande 2000 wildfire; Wagenbrenner et al., 2006). Consequently, it is compulsory to be effective and reach the goals of the post-fire rehabilitation policies. If the runoff and the soil erosion remain unknown, thus the efforts to restore will be inadequate or inappropriate. The "no intervention strategy" could be a realistic technique, but undoubtedly, it is unavoidable measuring and checking the extent of the post-fire hydrologic and erosive response. In order to overcome these uncertainties, and until the Portuguese soil erosion dataset can be large enough to feed the models in an adequate manner, a close collaboration between researchers and forest managers must be enhanced, especially when designing post-fire managements strategies or applying technical measures.

\section{Mitigation of soil erosion following wildfires}

The first efforts aiming to reduce soil erosion following wildfires were carried out in the USA (southern California), dating as far back as the late 1800s (Wohlgemuth et al., 2009). From then, the association of wildfire with on-site soil erosion and downstream flooding and massive sediment deposition became increasingly recognized and, in the early part of the last century, led to the first systematic soil erosion control treatments following wildfires (Munns, 1919). An event that alarmed the public opinion and highlighted the need for post-fire rehabilitation, took place on New Year's Day 1934, in La Crescenta, near Los Angeles. A debris flow deposited river tributaries to depths of up to $5 \mathrm{~m}$, transported boulders the size of automobiles over several kilometres, produced massive damage to properties and killed 16 persons (Kraebel, 1934).

During the first half of the $20^{\text {th }}$ century, post-fire rehabilitations efforts by and large consisted of building engineering structures (check dams) in stream channels to trap the sediments and of 
seeding hillslopes to increase ground cover. However, it proved to be unrealistic to build check dams in the often short periods between the occurrence of the wildfires and of the erosionproducing rains, so that they had to be constructed in advance of wildfires in streams and downstream of fire-prone areas (Wohlgemuth et al., 2009). On the other hand as early as the 1920s, seeding with native shrub species was recognized to be ineffective, since the introduced seeds germinated no earlier than the in-situ seed bank. Subsequent seeding trials with fastergrowing, non-native herbaceous species such as Mediterranean mustards (Brassica ssp.) led to problems in downstream agricultural areas, where the species were considered to be noxious weeds by the farmers. By the 1950s, however, seeding with ryegrass (Lolium multiflorum Lam.) had become widely regarded as the most cost-effective treatment for augmenting post-fire ground cover, at least in California (Wohlgemuth et al., 2009).

The effectiveness of seeding to mitigate post-fire soil erosion started to be questioned during the 1960s, in southern California. Namely, various studies had found that ryegrass seeding did not markedly reduce erosion even when effectively increased ground cover (Taskey et al., 1989). This ultimately led to a strong controversy on the effectiveness of seeding during the 1988 Symposium on Fire and Watershed Management, where various papers were presented that indicated the effectiveness of alternative post-fire treatments, i.e. application of straw mulch (Miles et al., 1989) and retaining of slash and residues from post-fire logging on the soil surface (Barker, 1989). From the above-cited studies, however, only one (Taskey et al., 1989) involved direct measurement of soil erosion rates on control and treated plots. Therefore, the symposium concluded to the need for standardization of treatment assessment methods, including a longer analysis of the time scale and a clear definition of the potential effects being evaluated, to provide land-use managers with better information to sustain their decisions (MacDonald, 1989). This author draw special attention to the fact that treatment effectiveness i.e. increase in ground cover- is not necessarily the same as achieving the goal of the treatment - i.e. reduction of post-fire sediment yields-.

During the 1990s and the 2000s, research on post-fire erosion mitigation concerned seeding (e.g. Pinaya et al., 2000; Fernández-Abascal et al., 2003; Beyers, 2004; Robichaud et al., 2006; Groen and Woods, 2008; Peppin et al., 2010), log barrier construction (Wagenbrenner et al., 2006; Robichaud et al., 2008), straw mulching (Bautista et al., 1996; Badía and Martí, 2000; Wagenbrenner et al., 2006) and several combination of two or more techniques (seeding + log erosion barriers + straw mulch in Dean, 2001 and seeding + mulch in Badía and Martí, 2000; see Fig. 4). In a nutshell, these studies found seeding to be effective in some cases but not in others, log barriers construction to be ineffective unless rain events are few and small, and mulching to be highly effective. The effectiveness of mulching is also well-established for agriculture lands (Harris and Yao, 1923; Meyer et al., 1970; Jordán et al., 2010), as well as cut slopes and unpaved roads (Grismer and Hogan, 2005; Jordán et al., 2008). In regions such as the USA, with a large experience in post-fire soil erosion control, the use of mulched based treatments has increased as seeding and erosion barriers have decreased (Robichaud, 2009), and recently, aerial application methods were found to be very useful for reaching inaccessible areas by roads, and more economic compared to hand or ground applications (Napper, 2006). In the Iberian Peninsula context, the first straw helimulch had been carried out by the Lourizán Forestry Research Center in Galicia (NW Spain). However, land managers are still unaware about the advantages of the mulch. Frequently, other treatments different than mulch, are still 
being applied for post-fire soil erosion control all over Europe, but unfortunately, most of the times its effectiveness in soil erosion reduction is not being assessed.

In Fig. 7 it is possible to compare the big bulk of the research studies carried out with forest residue mulch (blue), wood chips (orange), PAM (red), straw mulch (grey) and hydromulch (green). The studies that lie out near the $0 \%$ reduction line are those in which there were no differences in soil erosion between untreated and treated plots (such as the PAM or some hydromulch studies); while the ones lying out near the $90 \%$ reduction line are the more effective (such as the straw and the forest residue mulch). The effectiveness of straw mulches for mitigating post-fire erosion has been tested more exhaustively in field trials than that of mulches composed of woody plant materials. Often-cited advantages of straw mulches are their wide availability, low costs and low specific weights (Bautista et al., 1996; Wagenbrenner et al., 2006; Fernández et al., 2011). Nonetheless, the availability of straw mulches may be limited in many parts of the world (Foltz and Wagenbrenner, 2010). Furthermore, the low specific weights can also be a disadvantage, especially in areas prone to strong winds during the period between straw application and the first heavy rainfall events (Robichaud et al., 2000). Negative ecological effects of straw mulches were pointed out by Kruse et al. (2004), such as the reduction of the density of conifer seedlings and the involuntary introduction of non-native seeds. Wood chips were found to have little effect in reducing post-fire soil losses in various studies (Kim et al., 2008; Riechers et al., 2008; Fernández et al., 2011). This could be due to the shape and size of the chips. Laboratory rainfall simulation experiments found that wood shreds and strands were as effective as straw, whilst wood chips were not (Foltz and Dooley, 2003; Yanosek et al., 2006; Smets et al., 2008).
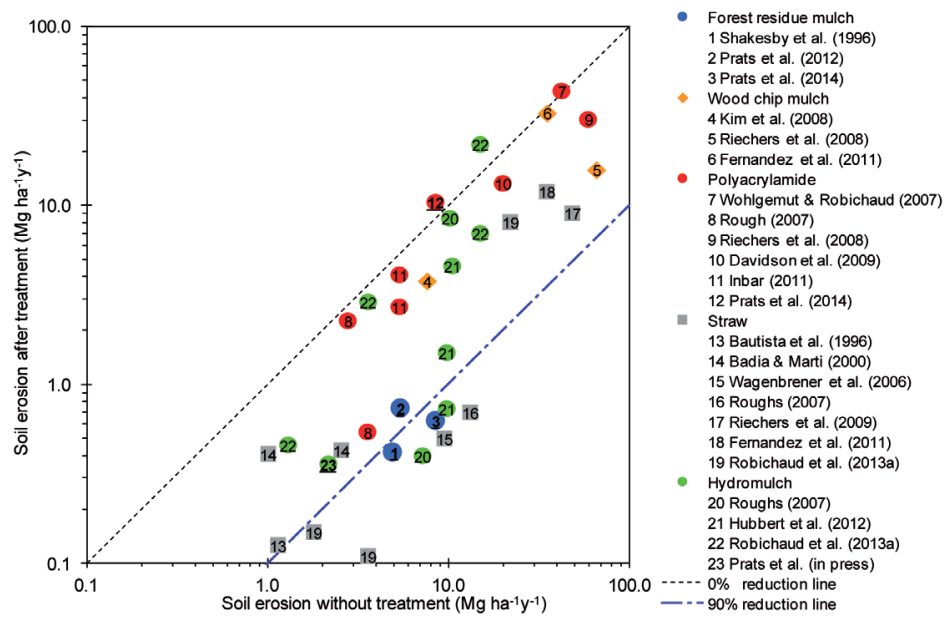

Figure 7. First year post-fire soil erosion rates from studies assessing the effectiveness of emergency treatments such as forest residue mulch (1 to 3), wood chip mulch (4 to 6), PAM (7 to 12), straw mulch (13 to 19) and hydromulch (20 to 23). The 0\% and $90 \%$ reduction lines were included to indicate no and high effectiveness, respectively. Numbers in bold and underlined were carried out in Portugal. 
A recent variant of mulching is that of hydromulching, involving the application of an aqueous mixture of organic fibres with seeds, nutrients, soil binding agents, green colorant and seeds from a jet hose (Naveh, 1975). Hydromulching is a relatively expensive technique, with a cost of $\$ 2300$ and $\$ 7400$ per ha for ground and aerial spreading, respectively (MacDonald and Larsen, 2009) as compared to $\$ 400-2900$ for ground to \$600-2300 for aerial straw mulch spreading (Napper, 2006; MacDonald and Larsen 2009). Hydromulching is typically used in restoration of degraded landscapes such as quarries, road banks, and highway cut slopes (Emanual, 1976; Benik et al., 2003; Robichaud et al., 2010), but has not been extensively used or tested in recently burnt areas (Wohlgemuth et al., 2011; Hubbert et al., 2012). In the last two studies hydromulching was effective in reducing post-fire erosion but, at the same time, it exhibited a quick breakdown. By contrast, Wohlgemuth et al. (2011) found it to be ineffective for high-intensity rainfall storms.

Also polyacrylamides (PAM) - a family of flocculant agents developed by the agrochemical sector- were recently introduced for post-fire erosion mitigation (Rough 2007; Wohlgemuth and Robichaud, 2007). Especially in the form of dry granulate, it can be applied easily. During the last two decades, PAM has become widely accepted for soil erosion control in intensive agriculture with furrow irrigation as well as on steep road embankments (Agassi and Ben-Hur, 1992; Lentz et al., 2002; Ben-Hur, 2006; Sojka et al., 2007). Since PAM is a generic term for a broad class of hundreds of polymers with differing functional groups and chain lengths, different formulations have been tested to achieve optimal binding of PAM with the soils' specific clay particles, through direct ionic attractions or cation bridges (Vacher et al., 2003). So far, few field trials have assessed the effectiveness of PAM in recently burnt areas, and these studies have reported opposing results. Whilst Davidson et al. (2009), Riechers et al. (2008) and Inbar (2011) found PAM to be effective in reducing post-fire erosion, Rough (2007), Wohlgemuth and Robichaud (2007) and Macdonald and Larsen (2009) did not (see Fig. 7).

The log and shrub erosion barriers have been used extensively, mostly because the materials (logs, stems, shrubs) are already on the field. However, their efficacy has proved to be much lower, dependent on log storage capacity and the occurrence of small rainfall events, whilst the costs are similar to the mulching (Wagenbrenner et al., 2006). In this sense, the study of the Lourizán Forestry Research Center (Fernández et al., 2011) illustrates very well the low effectiveness of shrub erosion barriers when compared to straw (see Fig. 4). In the words of Bautista: "It is very difficult to fail in applying mulch, but it is very easy to fail in installing log erosion barriers". In fact, Robichaud et al. (2008) verified that $32 \%$ of their log erosion barriers did not have good contact with the ground surface, and $38 \%$ were moved off contour. More precise measurements showed that less than half of the total length of the contour-felled logs effectively stored the runoff and the sediments.

Some labor intensive treatments as contour trenches across the slope with a bulldozer, channel stabilization structures, side slope stabilizations and scarification of the soil surface (MacDonald and Larsen, 2009) have been shown to be ineffective for reducing soil erosion. In Portugal, post-fire ground interventions such as ploughing and rip-ploughing have showed to increase dramatically the runoff and the soil erosion 
(Ferreira et al., 1997; Shakesby et al., 2002; Martins et al., 2013). Some of these ground disturbing measures altered the sediment fluxes across the slope and continue to persist long after the emergency is over (Rice et al., 1965; Keizer et al., 2008; Malvar et al., 2011, 2013).

\subsection{Effectiveness of post-fire erosion mitigation treatments in north-central Portugal}

Forest residue mulches are (potentially) widely available in forest-dominated areas such as north-central Portugal, and many other European countries (Fig. 8). Positive results were found after the first field experiment carried out with eucalypt and pine logging litter (Shakesby et al., 1996; Table 1), but involved the application of heavy loads of materials. At lower application rates, Prats et al. $(2012,2014)$ found that chopped eucalypt bark mulch (blue circles in Fig. 7) providing an initial ground cover of 70-80\% reduced post-fire runoff and erosion to a similar extent as straw mulching (grey squares in Fig. 7). At the same time, the chopped eucalypt bark mulch had important advantages, such as to be less susceptible to removal by wind, and lower decomposition rate compared to the straw. Reductions in both overland flow and soil losses were somewhat lower at the eucalypt plantation in the Pessegueiro than Ermida study area (40\% vs. 50\% and 85\% vs. $90 \%$, respectively), possibly due to the higher application rate in the latter case (8.7 vs. $10.8 \mathrm{Mg} \mathrm{ha}^{-1}$ ).
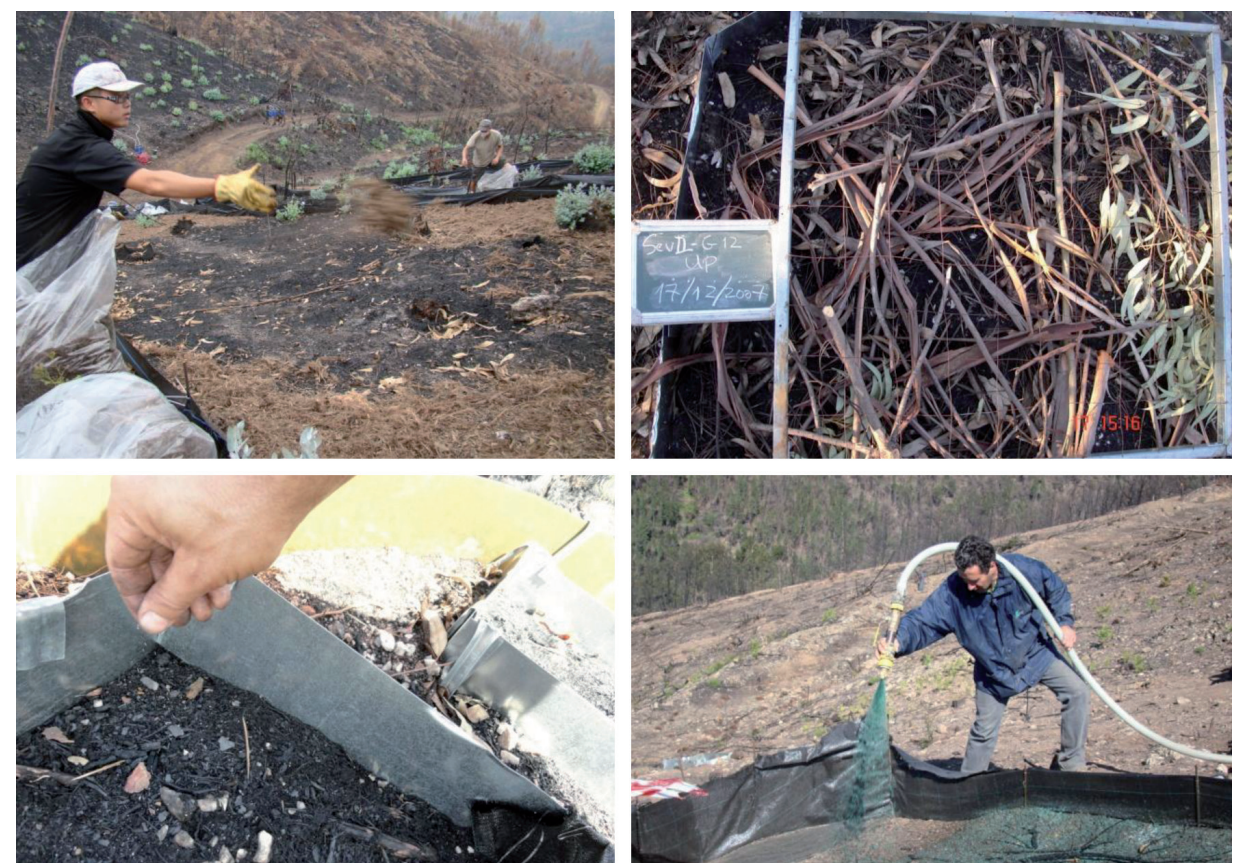

Figure 8. Illustration of the application of the treatments assessed in Portugal: eucalypt chopped bark mulch (Prats et al. 2012, 2014; top left), eucalypt logging slash mulch (Shakesby et al., 1996; Prats et al. 2012; top right), dry polyacrylamide (Prats et al., 2014; bottom left) and jethose hydromulching (Prats et al., 2013; bottom right). 
The eucalypt logging slash mulch applied at the Pessegueiro pine site, however, appeared to enhance post-fire soil erosion. The same applied to the nearby pine site that Shakesby et al. (1996) treated with logging slash mulch and to the PAM applied in the Ermida wildfire (Table 1). This increase in the soil erosion on the treated plots compared to the control ones was attributed to the use of a low number of plots and the low soil erosion rates measured on the control plots. In fact, these low erosion rates were the consequence of a "natural" mulching of the untreated plots by leaf and needle cast. A marked reduction in erosion by post-fire needle cast was also reported by Cerdà and Doerr (2008). Arguably, however, the main disadvantage of mulching with logging slash is the elevated application rate of 18 to $47 \mathrm{Mg} \mathrm{ha}^{-1}$ that is needed to achieve the widely-recommended ground cover of $70 \%$.

The hydromulching applied at the pine site in Colmeal (Fig. 8) by Prats et al. (2013) was highly effective, reducing runoff in $70 \%$ and soil losses in $80 \%$. These figures were somewhat better than those reported by three studies evaluating hydromulching in recently burnt areas (Rough, 2007; Wohlgemuth et al., 2011; Hubbert et al., 2012); possibly due to the lower-than-hoped application rates in the three studies as a result of the interception of the spraying jet by the burnt but still upright trees. The observed decrease in hydromulch cover was pronounced (4 - 5\% per month) but comparable to the three above-mentioned field trials. In this study, this decay was largely compensated by the introduced seeds, which did not happened on the previous USA studies. Beyers (2004) pinpointed to the risks of introducing invasive weeds, but the plants introduced at the Colmeal plots with the hydromulch had almost disappeared two years later.

The dry granular polyacrylamide (Fig. 8) applied by Prats et al. (2014) was ineffective to decrease post-fire runoff or the associated soil losses. In fact, Fig. 7 shows clearly that PAM studies lie out over the $0 \%$ reduction line (meaning no effectiveness), while hydromulch exhibited an intermediate position and lately, both forest residue and straw mulch lie out near the $90 \%$ reduction line. The reduced effectiveness of PAM was possibly due to its preferential binding to the ashes in combination with the subsequent removal of the bulk of these ashes by the runoff, similar to what was reported by Rough (2007) and Wallace and Wallace (1986a). Future testing of PAM in recently burnt areas should perhaps focus on find if it could be advantageous when combined with mulching (Riechers et al., 2008; Davidson et al., 2009). On the other hand, the possibility exists that other PAM formulations could be more appropriate for the soils studied here, in the presence of a noticeable ash layer and/or with their relatively low clay contents (Sojka et al., 2007). Whilst PAM is a very promising product, including in terms of costs, its successful application in recently burnt areas is thus far from straightforward, as also found by Rough (2007) and Wohlgemuth and Robichaud (2007).

Far from being obvious, the selected treatment must be effective in reducing post-fire soil erosion. Innumerous examples exist in which treatment effectiveness was confounded with treatment goal. For example, citing Wagenbrenner et al. 
(2006): "Studies on the effectiveness of seeding have tended to measure changes in cover rather than erosion rates". Similarly, the potential treatment should be costeffective compared to alternative treatments. Table 2 shows a cost-benefit analysis for the most commonly applied post-fire soil erosion control treatments not only in Portugal but also in the USA (following Napper, 2006 and Wagenbrenner et al., 2006). The difference in the application rates between straw and forest residues (2.2 vs. $8 \mathrm{Mg} \mathrm{ha}^{-1}$ ) will largely compensate their differences in price per unit of weight (roughly 150 vs. $30 €$ per $\mathrm{Mg}$ ). Mulching with straw or chopped bark were the most cost-effective, especially when compared to the hydromulching, which despite to be effective was very expensive. The choice between the first two alternatives will easily come to depend on the availability of the straw and chopped bark in sufficient quantities. In north-central Portugal, this will most likely be eucalypt chopped bark. However, in the case of recently burnt pine, oak or shrublands the application of eucalypt chopped bark will be less recommendable than chopped bark from native tree or shrub species.

The contribution of Prats et al. $(2012,2013,2014)$ to the determination of the main factors affecting runoff and soil erosion was possible due to intensive monitoring of the field plots, achieving the weekly variations in rainfall characteristics, soil cover and some soil properties. The effect of mulch, in a pool including all the control and treated plots, consisted of a shifting to -or strength of- rainfall intensity as first variable explaining both runoff and soil erosion. The importance of litter increased, explaining from a third to half of soil erosion. The physical factors (rainfall characteristics, soil water repellence, soil moisture and time-invariant soil properties) were not important for the treatments that provide immediate ground cover, (chopped bark mulch, slash logging mulch and hydromulching) due to the protection that the organic cover provided against soil detachment and increased soil water storage, and thereby immediately reduce overland flow and soil erosion. However, this was not true for the PAM because it did not affect the ground cover. The strongest position of litter as a key factor explaining post-fire soil erosion was achieved by the most effective treatment (the chopped bark mulch in Ermida, 32\% of variation explained) but also by the longest monitoring period (the hydromulch in Colmeal, $55 \%$ of variation).

In spite of the improvement on the post-fire soil erosion mitigation knowledge, further research is needed. On one hand, the techniques tested showed some disadvantages: the forest residue mulch is very heavy, the straw very light, the hydromulch very expensive, and the PAM was not effective. An optimum balance for soil erosion control must be found by combining different materials (organic and chemical) and using different spreading methods (hand, blowing, aerial, chopping in situ, etc.). On other hand, the assessment of an intervention requires good quality field data series. Soil erosion control is the first line of a burnt area emergency response (MacDonald, 1994) but other issues such as wildfire effects on the forest ecosystem functions and off-site consequences will need, respectively, longer time data series and larger spatial-scale assessment. 


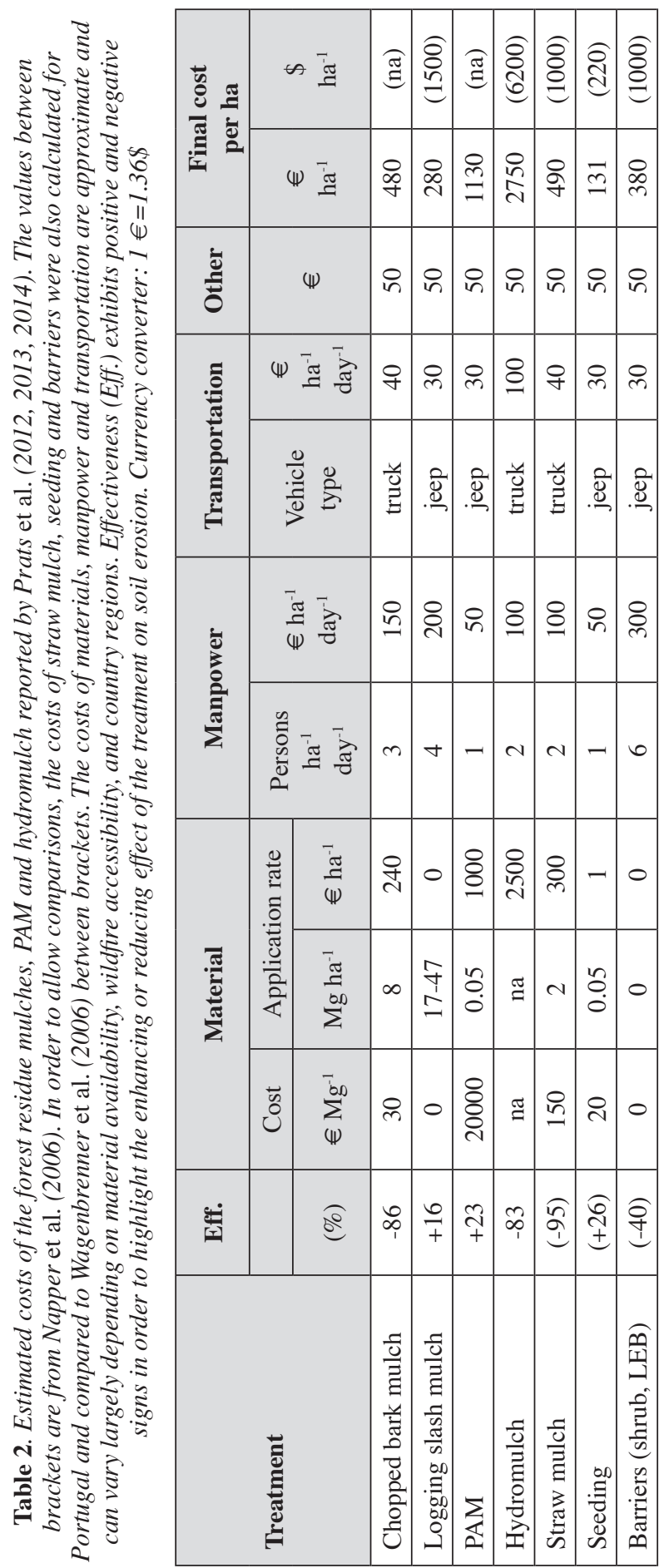




\section{Conclusions and management implications}

The revision of the recent literature on the matter carried out here point out to the following conclusions:

1. Post-fire soil losses in north-central Portugal during the first year after wildfire tend to be relatively low when compared with other parts of the world, but they are still high compared to the soil formation rates estimates. Nonetheless, the organic matter contents were invariably half on the eroded sediments, which can compromise on-site soil fertility and carbon fixation and off-site water pollution.

2. Burnt areas attaining a leaf or needle carpet from the scorched tree canopies around $50-60 \%$ of the soil surface are not susceptible to be treated because the soil erosion risk in these areas will be low.

3. The chopped bark mulching was as cost-effective as straw mulching, reducing runoff by $40 \%$ and soil erosion by $85 \%$ through an increase in ground cover of $70 \%$;

4. The polyacrylamides applied in dry form did not reduce soil erosion and, thus, cannot be recommended for mitigating post-fire soil erosion. Because of PAM's elevated potential and low costs, however, further work seems justified, especially to diminish the possible preferential biding to ash rather than soil particles;

5. The hydromulch was basically as effective in reducing post-fire runoff and erosion as the chopped bark mulch. Despite its much higher costs its use could be justified where "values at risk" are high, whether in economic, cultural or safety terms, or where recovery of the spontaneous vegetation is strongly compromised.

Several management implications can be pointed out after this research review. Stakeholders, land managers, governments and forestry institutions must be aware of these improvements. Field indicators of non tolerable post-fire soil erosion rates (slope angle, ground cover and ash colour) were found. These indicators can address the post-fire emergency interventions on areas susceptible to trigger on-site and off-site effects and compromise values at risk. In the case of an urgent intervention, mulching will become the more advantageous technique. In other situations, where the previous conditions were not meet (such as the Pessegueiro pine site or the Açores ploughed site), the "no intervention" option would be preferred (Robichaud, 2009; Bautista et al., 2009).

\section{Acknowledgements}

This research was supported financially through the $\mathrm{PhD}$ grants attributed to SPA, (SFRH/BD/33392/2008) and MMC (SFRH/BD/41320/2007) in the framework of the IV program as well as by the RECOVER, EROSFIRE, EROSFIRE-II, and FIRECNUTS FCT- projects, funded by the FCT/MCTES (PIDDAC), with co-funding by FEDER through COMPETE (Programa Operacional Factores de Competitividade; POFC). We are further much indebted to the soil erosion crew of CESAM, Dept. Environment and Planning, of the University of Aveiro for their active help during the field installation and 
monitoring of the plots. The two anonymous reviewers are also gratefully acknowledged for their help in improving this manuscript.

\section{References}

Agassi, M., Ben-Hur, M. 1992. Stabilizing steep slopes with soil conditioners and plants. Soil Technology 5, 249-256.

Alexander, E.B. 1988. Rates of soil formation: implications for soil loss tolerance. Soil Science $145,37-45$.

Andreu, V., Imeson, A.C., Rubio, J.L. 2001. Temporal changes in soil aggregates and water erosion after a wildfire in a Mediterranean pine forest. Catena 44, 69-84.

Autoridade Florestal Nacional (AFN), 2013. Estatística - dados sobre incêndios florestais. Available at: http://www.afn.min-agricultura.pt/portal/dudf/estatisticas (last access: 01/05/2013).

Badía, D., Martí, C. 2000. Seeding and mulching treatments as conservation measures of two burned soils in the central Ebro valley, NE Spain. Arid Soil Research and Rehabilitation 13, 219-232.

Barker, P.F. 1989. Timber salvage operations and watershed resources values. In Proceedings of the Symposium on Fire and Watershed Management, October 1988, Sacramento, California, GTR-PSW-109, U.S. Department of Agriculture, Forest Service, Pacific Southwest Forest and Range Experiment Station, pp 1-2.

Bautista, S., Bellot, J., Vallejo, V.R. 1996. Mulching treatment for post-fire soil conservation in a semiarid ecosystem. Arid Soil Research and Rehabilitation 10, 235-242.

Bautista, S., Robichaud, P.R., Bladé, C. 2009. Post-fire mulching. In Fire effects on soils and restoration strategies, A. Cerdá, P. R. Robichaud (eds.), Science Publishers, Enfield, NH, USA, pp. 353-372.

Benavides-Solorio, J.D.D., MacDonald, L.H. 2005.Measurement and prediction of post-fire erosion at the hillslope. International Journal of Wildland Fire 14, 457-474.

Ben-Hur, M. 2006. Using synthetic polymers as soil conditioners to control runoff and soil loss in arid regions - a review. Australian Journal of Soil Research 44, 191-204.

Benik, S.R., Wilson, B.N., Biesboer, D.D., Hansen, B., Stenlund, D. 2003. Evaluation of erosion control products using natural rainfall events. Journal of Soil and Water Conservation 58, 98-105.

Beyers, J.L. 2004. Postfire seeding for erosion control: Effectiveness and impacts on native plant communities. Conservation Biology 18 (4), 947-956.

Bird, R.B., Bird, D.W., Codding, B.F., Parker, C.H., Jones, J.H. 2008. The "fire stick farming" hypothesis Australian Aboriginal foraging strategies, biodiversity, and anthropogenic fire mosaic. Proceedings of the National Academy of Sciences 105, 14796-14801.

Cerdà, A., Doerr, S.H. 2007. Soil wettability, runoff and erodibility of major dry-Mediterranean land use types on calcareous soils. Hydrological Processes 21, 2325-2336.

Cerdà, A., Doerr, S.H. 2008. The effect of ash and needle cover on surface runoff and erosion in the immediate post-fire period. Catena 74, 256-263.

Cerdà, A., Imeson, A.C., Calvo, A. 1995. Fire and aspect induced differences on the erodibility and hydrology of soils at La Costera, Valencia, southeast Spain. Catena 24, 289-304.

Coelho, C.O.A., Ferreira, A.D.J., Boulet, A.K., Keizer, J.J.K. 2004. Overland flow generation processes, erosion yields and solute loss following different intensity fires. Quarterly Journal of Engineering Geology and Hydrogeology 37, 233-240.

Davidson, R.A., Davidson, C.F., Roa-Espinosa, A. 2009. Linear anionic polyacrylamide as an effective post-fire soil treatment: understanding the chemistry and physical science. Journal of Soil and Water Conservation 64, 243-252. 
Dean, A.E. 2001. Evaluating effectiveness of watershed conservation treatments applied after the Cerro Grande Fire, Los Alamos, New Mexico. MSc thesis. AZ, 116 University of Arizona, Tucson.

DeBano, L.F. 2000. The role of fire and soil heating on water repellency in wildland environments: a review. Journal of Hydrology 231-232, 195-206.

DeBano, L.F., Neary, D.G., Folliott, P.F. 1998. Fire's effects on ecosystems. John Wiley \& Sons, New York, 352 pp.

Doerr, S.H., Shakesby, R.A., Walsh, R.P.D. 1996. Soil hydrophobicity variations with depth and particle size fraction in burned and unburned Eucalyptus globulus and Pinus pinaster forest terrain in the Águeda Basin, Portugal. Catena 27, 25-48.

Doerr, S.H., Shakesby, R.A., Walsh, R.P.D. 2000. Soil hydrophobicity: its causes, characteristics and hydro-geomorphological significance. Earth-Science Reviews 51, 33-65.

Emanual, D.M. 1976. Hydromulch: a potential use for hardwood bark residue. USDA Forest Service Research Note NE-226.

Fernández, C., Vega, J.A., Gras, J.M., Fonturbel, T., Cuiñas, P., Dambrine, E., Alonso, M. 2004. Soil erosion after Eucalyptus globulus clearcutting: differences between logging slash disposal treatments. Forest Ecology and Management 195, 85-95.

Fernández, C., Vega, J.A., Jiménez, E., Fonturbel, T. 2011. Effectiveness of three post-fire treatments at reducing soil erosion in Galicia (NW Spain). International Journal of Wildland Fire 20 (1), 104-114.

Fernández-Abascal, I., Tárrega, R., Luis-Calabuig E., Marcos E. 2003. Effects of sowing native herbaceous species on the post-fire recovery in a heathland. Acta Oecologica 24, 131-138.

Ferreira, A.J.D., Coelho, C.O.A., Shakesby, R.A., Walsh, R.P.D. 1997. Sediment and solute yield in forest ecosystems affected by fire and rip-ploughing techniques, central Portugal: a plot and catchment analysis approach. Physics and Chemistry of the Earth 22, 309-314.

Ferreira, A.J.D., Coelho, C.O.A., Ritsema, C.J., Boulet, A.K., Keizer, J.J. 2008. Soil and water degradation processes in burned areas: lessons learned from a nested approach. Catena 74, 273-285.

Figueiredo, T., Fonseca, F., Martins, A. 2011. Soil loss and run-off in young forest stands affected by site preparation technique: a study in NE Portugal. European Journal of Forest Research 131 (6), 1747-1760.

Foltz, R.B., Dooley, J.H. 2003. Comparison of erosion reduction between wood strands and agricultural straw. Transactions of the ASAE 46 (5), 1389-1396.

Foltz, R.B., Wagenbrenner, N.S. 2010. An evaluation of three wood shred blends for post-fire erosion control using indoor simulated rain events on small plots. Catena 80, 86-94.

Fox, D.M., Darboux, F., Carrega, P. 2007. Effects of fire-induced water repellency on soil aggregate stability, splash erosion and saturated hydraulic conductivity for different size fractions. Hydrological Processes 21, 2377-2384.

Giovannini, G., Lucchesi, S., Giachetti, M. 1988. Effect of heating on some physical and chemical parameters related to soil aggregation and erodibility. Soil Science 146, 255-261.

González-Pelayo, O., Andreu, V., Campo, J., Gimeno-García, E., Rubio, J.L. 2006. Hydrological properties of a Mediterranean soil burned with different fire intensities. Catena 68, 186-193.

Grismer, M.E., Hogan, M.P. 2005. Simulated rainfall evaluation of revegetation/mulch erosion control in the Lake Tahoe basin - 3: soil treatment effect. Land Degradation \& Development 16: 489-501.

Groen, A.H., Woods, S.W. 2008. Effectiveness of aerial seeding and straw mulch for reducing post-wildfire erosion, north-western Montana, USA. International Journal of Wildland Fire 17, 559-571. 
Guerrero, C., Mataix-Solera, J., Arcenegui, V., Mataix-Beneyto, J., Gómez, I. 2007. Nearinfrared spectroscopy to estimate the maximum temperatures reached on burned soils. Soil Science Society of America Journal 71 (3), 1029-1037.

Harris, F.S., Yao, H.H. 1923. Effectiveness of mulches in preserving soil moisture. Journal of Agricultural Research 9, 727-742.

Hubbert, K.R., Wohlgemuth, P.B., Beyers J.B. 2012. Effects of hydromulch on post-fire erosion and plant recovery in chaparral shrublands of southern California. International Journal of Wildland Fire 21,155-167.

ICNF-MAMAOT (Instituto da Conservação da Natureza e das Florestas - Ministério da Agricultura, Mar, Ambiente e Ordenamento do Território) 2013. 6. ${ }^{\circ}$ Inventário Florestal Nacional Áreas dos usos do solo e das espécies florestais de Portugal continental - Resultados preliminares. 34 pp. Available at: http://www.icnf.pt/portal/florestas/ifn/ifn6 (last access: 01/01/2014).

Imeson, A.C., Verstraten, J.M., Van Mullingen, E.J., Sevink, J. 1992. The effects of fire and water repellency on infiltration and runoff under Mediterranean type forests. Catena 19, 345-361.

Inbar, A. 2011. Using synthetic polymers for soil erosion control after forest fires. MSc Thesis, Tel-Aviv University.

Inbar, M., Tamir, M., Wittenberg, L. 1998. Runoff and erosion processes after a forest fire in Mount Carmel, a Mediterranean area. Geomorphology 24, 17-33.

Jandl, R., Lindner M., Vesterdal, L., Bauwens, B., Baritz R., Hagedorn F., Johnson DW., Minkkinen K., Byrne K.A. 2007. How strongly can forest management influence soil carbon sequestration? Geoderma 137, 253-268.

Jordán, A., Martínez-Zavala, L. 2008. Soil loss and runoff rates on unpaved forest roads in southern Spain after simulated rainfall. Forest Ecology and Management 255, 913-919.

Jordán, A., Zavala, L. M., Gil, J. 2010. Effects of mulching on soil physical properties and runoff under semi-arid conditions in southern Spain. Catena 81, 77-85.

Keizer, J.J., Doerr, S.H., Malvar, M.C., Prats, S.A., Ferreira, R.S.V., Oñate, M.G., Coelho, C.O.A., Ferreira, A.J.D. 2008. Temporal variation in topsoil water repellence in two recently burnt eucalypt stands in north-central Portugal. Catena 74 (3), 192-204.

Kim, C-G., Shin, K., Joo, K-Y., Lee K-S., Shin, S-S., Choung Y. 2008. Effects of soil conservation measures in a partially vegetated area after forest fires. Science of The Total Environment 399, 158-164.

Kraebel, C.J. 1934. The La Crescenta flood. American Forest 40, 251-254.

Kruse, R., Bend, E., Bierzychudek, P. 2004. Native plant regeneration and introduction of nonnatives following post-fire rehabilitation with straw mulch and barley seeding. Forest Ecology and Management 196, 299-310.

Kutiel, P., Inbar, M. 1993. Fire impacts on soil nutrients and soil erosion in a Mediterranean pine forest plantation. Catena 20, 129-139.

Lavabre, J., Torres, D.S., Cernesson, F. 1993. Changes in the hydrological response of a small Mediterranean basin a year after a wildfire. Journal of Hydrology 142, 273-299.

Leighton-Boyce, G., Doerr, S.H., Shakesby, R.A., Walsh, R.P.D. 2007. Quantifying the impact of soil water repellency on overland flow generation and erosion: a new approach using rainfall simulation and wetting agent on in situ soil. Hydrological Processes 21, 2337-2345.

Lentz, R.D., Sojka, R.E., Makey, B.E. 2002. Fate and Efficacy of Polyacrylamide Applied in Furrow irrigation: Full-Advance and Continuous Treatments. Journal of Environmental Quality 31, 661-670.

Llovet, J., Ruiz-Valera, M., Josa, R., Vallejo, V.R. 2009. Soil responses to fire in Mediterranean forest landscapes in relation to the previous stage of land abandonment. International Journal of Wildland Fire 18, 222-232. 
MacDonald, L.H. 1989. Rehabilitation and Recovery Following Wildfires: A Synthesis. In Proceedings of the Symposium on Fire and Watershed Management, October 1988, Sacramento, California, GTR-PSW-109. U.S. Department of Agriculture, Forest Service, Pacific Southwest Forest and Range Experiment Station, pp. 141-144.

MacDonald, L.H. 1994. Developing a monitoring project. Journal of Soil and Water Conservation 4, 221-227.

MacDonald, L.H., Larsen, I. 2009. Effects of forest fires and post-fire rehabilitation: a Colorado, USA case study. In Fire effects on soils and restoration strategies, A. Cerdá, P. R. Robichaud (eds.), Science Publishers, Enfield, NH, USA, pp. 423-452.

Maia, P., Pausas, J.G., Arcenegui, V., Guerrero, C., Pérez-Bejarano, A., Mataix-Solera, J., Varela, M.E.T., Fernandes, I., Pedrosa, E.T., Keizer, J.J. 2012. Wildfire effects on the soil seed bank of a maritime pine stand - the importance of fire severity. Geoderma 191, 80-88.

Malvar, M.C. 2013. Assessing the combined effect of land management and wildfire on runoff and soil erosion in North Central Portugal. PhD Thesis, University of Aveiro.

Malvar, M.C., Prats, S.A., Nunes, J.P., Keizer, J.J. 2011. Post fire overland flow generation and inter rill erosion under simulated rainfall in two eucalypt stands in north-central Portugal. Environmental Research 111, 222-236.

Malvar, M.C., Martins, M.A.S., Nunes, J.P., Robichaud, P.R., Keizer, J.J. 2013. Assessing the role of pre-fire ground preparation operations and soil water repellency in post-fire runoff and inter-rill erosion by repeated rainfall simulation experiments in Portuguese eucalypt plantations. Catena 108, 69-83.

Martins, M.A.S., Machado, A.I., Serpa, D., Prats, S.A., Faria, S.R., Varela, M.E.T., GonzalezPelayo, O., Keizer, J.J. 2013. Runoff and inter-rill erosion in a Maritime Pine and a eucalypt plantation following wildfire and terracing in north-central Portugal. Journal of Hydrology and Hydromechanics 60, 261-268.

Meyer, L.D., Wischmeier, W.H., Foster, G.R. 1970. Mulch rates required for erosion control on steep slopes. Soil Science Society American Proceedings 34, 928-931.

Miles, S.R., Haskins, D.M., Ranken, D.W. 1989. Emergency burn rehabilitation: Cost, risk, and effectiveness. In Proceedings of the Symposium on Fire and Watershed Management, October 1988, Sacramento, California, GTR-PSW-109. U.S. Department of Agriculture, Forest Service, Pacific Southwest Forest and Range Experiment Station, pp. 97-102.

Moreno, J.M., Oechel, W.C. 1989. A simple method for estimating fire intensity after a burn in California chaparral. Acta Oecologica 10, 57-68.

Morgan, R.P.C. 2005. Soil Erosion and Conservation, Third Edition. Blackwell Science Ltd., London.

Munns, E.N. 1919. The control of flood water in southern California. Journal of Forestry, 17, 423-429.

Napper, C. 2006. The burned area emergency response treatment catalog (BAERCAT). Tech. Rep. 0625 1801-SDTDC. Washington DC: U.S. Department of Agriculture, Forest Service, National Technology \& Development Program, Watershed, Soil, Air Management. 253 pp. Available at: http://www.fs.fed.us/eng/pubs/pdf/BAERCAT/lo_res/06251801L.pdf (last access: 19/06/2009).

Naveh, Z. 1975. Degradation and rehabilitation of Mediterranean land-scapes: Neotechnological degradation of Mediterranean landscapes and their restoration with drought resistant plants. Landscape Planning 2, 133-146.

Peppin, D., Fulé P.Z., Sieg, C.H., Beyers, J.L., Hunter, M.E. 2010. Post-wildfire seeding in forests of the western United States: An evidence-based review. Forest Ecology and Management $260,573-586$. 
Pinaya, I., Soto, B. Arias, M., Díaz-Fierros, F. 2000. Revegetation of burnt areas: relative effectiveness of native and commercial seed mixtures. Land Degradation \& Development 11, 93-98.

Prats, S. A., MacDonald, L.H., Monteiro, M.S.V., Ferreira, A.J.D., Coelho, C.O.A., Keizer, J.J. 2012. Effectiveness of forest residue mulching in reducing post-fire runoff and erosion in a pine and a eucalypt plantation in north-central Portugal. Geoderma 191, 115-124.

Prats, S.A., Malvar, M.C., Vieira, D.C.S., Keizer, J.J. 2013. Effectiveness of hydromulching to reduce runoff and erosion in a recently burnt and logged Maritime Pine stand in north-central Portugal. Land Degradation \& Development. DOI: 10.1002/ldr.2236.

Prats, S.A., Martins, M.A.S., Malvar, M.C., Ben-Hur, M., Keizer, J.J. 2014. Polyacrylamide application versus forest residue mulching for reducing post-fire runoff and soil erosion. Science of the Total Environment 468, 464-474.

Prosser, I.P., Williams, L. 1998. The effect of wildfire on runoff and erosion in native Eucalyptus forest. Hydrological Processes 12, 251-265.

Rice, R.M., Crouse, R.P., Corbett, E.S. 1965. Emergency measures to control erosion after a fire on the San Dimas Experimental Forest. In Federal Interagency Sedimentation Conference Proceedings, Misc. Pub. 970, U.S. Department of Agriculture, pp. 123-130.

Riechers, G.H., Beyers, J.L., Robichaud, P.R., Jennings, K., Kreutz, E., Moll, J. 2008. Effects of three mulch treatments on initial post-fire erosion in North-Central Arizona. In Proceedings of the 2002 fire conference: Managing fire and fuels in the remaining wildlands and open spaces of the Southwestern United States, M.G. Narog (ed.), Gen. Tech. Rep. PSW-GTR-189.

Robichaud, P.R. 2000. Fire effects on infiltration rates after prescribed fire in Northern Rocky Mountain forests, USA. Journal of Hydrology 231-232, 220-229.

Robichaud, P.R. 2009. Post-fire stabilization and rehabilitation. In Fire effects on soils and restoration strategies, A. Cerdá, P. R. Robichaud (eds.), Science Publishers, Enfield, NH, USA, pp. 299-320.

Robichaud, P.R., Beyers J.L., Neary D.G. 2000. Evaluating the effectiveness of postfire rehabilitation treatments. General Technical Report RMRS-GTR-63, Department of Agriculture, Forest Service, Rocky Mountain Research Station, Fort Collins, Colorado, USA, 85 pp.

Robichaud, P.R., Lillybridge, T.R., Wagenbrenner, J.W. 2006. Effects of postfire seeding and fertilizing on hillslope erosion in north-central Washington, USA. Catena 67, 56-67.

Robichaud, P.R., Wagenbrenner, J.W., Brown, R.E., Wohlgemuth, P.M., Beyers, J.L. 2008. Evaluating the effectiveness of contour-felled log erosion barriers as a post-fire runoff and erosion mitigation treatment in the Western United States. International Journal of Wildland Fire 17, 255-273.

Robichaud, P.R., Ashmun L.E., Sims B.D. 2010. Post-Fire Treatment Effectiveness for Hillslope Stabilization. General Technical Report RMRS-GTR-240. US Department of Agriculture, Forest Service, Rocky Mountains Research Station.

Robichaud, P.R., Lewis, S.A., Wagenbrenner, J.W., Ashmun, L.E., Brown, R.E. 2013a. Post-fire mulching for runoff and erosion mitigation Part I: Effectiveness at reducing hillslope erosion rates. Catena 105, 75-92.

Robichaud, P.R., Wagenbrenner, J.W., Lewis, S.L., Ashmun, L.E., Brown, R.E., Wohlgemuth, P.M. 2013b. Post-fire mulching for runoff and erosion mitigation Part II: Effectiveness in reducing runoff and sediment yields from small catchments. Catena 105, 93-111.

Rough, D., 2007. Effectiveness of rehabilitation treatments in reducing postfire erosion after the Hayman and Schoonover fires, Colorado Front Range. MSc Thesis, Colorado State University, Fort Collins. CO, USA. 
Ryan, K., Noste, N. 1985. Evaluating prescribed fires. In Proceedings of the Symposium and Workshop on Wilderness Fire, J. Lotan, B. Kilgore, W. Fischer, R. Mutch (eds.), GTR INT182, USDA Forest Service, Ogden, pp. 230-238.

Shakesby, R.A. 2011. Post-wildfire soil erosion in the Mediterranean: Review and future research directions. Earth-Science Reviews 105, 71-100.

Shakesby, R.A., Doerr S.H. 2006. Wildfire as a hydrological and geomorphological agent. EarthScience Reviews 74, 269-307.

Shakesby, R.A., Coelho, C.O.A., Ferreira, A.J.D., Terry, J.P., Walsh, R.P.D. 1994. Fire, postburn land management practice and soil erosion response curves in eucalyptus and pine forests, north-central Portugal. In Soil Erosion as a Consequence of Forest Fires, M. Sala, J.L. Rubio (eds.), Geoforma Ediciones, Logroño, pp. 111-132.

Shakesby, R.A., Boakes, D.J., Coelho, C.O.A., Gonçalves, A.J.B., Walsh, R.P.D. 1996. Limiting the soil degradational impacts of wildfire in pine and eucalyptus forests in Portugal. Applied Geography 16, 337-335.

Shakesby, R.A., Coelho, C.O.A., Ferreira, A.J.D., Walsh, R.P.D. 2002. Ground-level changes after wildfire and ploughing in eucalyptus and pine forests, Portugal: implications for soil microtopographical development and soil longevity. Land Degradation \& Development 13 , 111-127.

Sheridan, G.J., Lane, P.N.J., Noske, P.J. 2007. Quantification of hillslope runoff and erosion processes before and after wildfire in a wet Eualyptus forest. Journal of Hydrology 343, $12-28$.

Smets, T., Poesen, J., Knapen, A. 2008. Spatial scale effects on the effectiveness of organic mulches in reducing soil erosion by water. Earth-Science Reviews 89, 1-12.

Sojka, R.E., Bjorneberg, D.L., Entry, J.A., Lentz, R.D., Orts, W.J. 2007. Polyacrylamide in Agriculture and Environmental Land Management. Advances in Agronomy 92, 75-162.

Soto, B. 1993. Influencia de los incendios forestales en la fertilidad y erosionabilidad de los suelos de Galicia. PhD thesis, Universidad de Santiago de Compostela, 340 pp.

Soto, B., Diaz-Fierros, F. 1998. Runoff and soil erosion from areas of burnt scrub: comparison of experimental results with those predicted by the WEPP model. Catena 31, 257-270.

Soto, B., Basanta, R., Diaz-Fierros, F. 1993. Influence of wildland fire on surface runoff from a hillslope. Acta Geologica Hispanica 28, 95-102.

Spigel, K.M., Robichaud, P.R. 2007. First-year post-fire erosion rates in Bitterroot National Forest, Montana. Hydrological Processes 21, 998-1005.

Swanson, F.J. 1981. Fire and geomorphic processes. In Proceedings of the Conferenceon Fire Regimes and Ecosystem Properties, H.A. Mooney, T.M. Bonnicksen, N.L. Christiansen, J.E. Lotan, W.A. Reiners (eds.), USDA, Forest Service, GTR WO-26, Washington DC, pp. 401421.

Taskey, R., Curtis, C.L., Stone, J. 1989. Wildfire, ryegrass seeding, and watershed rehabilitation. In Proceedings of the Symposium on Fire and Watershed Management, October 1988, Sacramento, California, GTR-PSW-109. U.S. Department of Agriculture, Forest Service, Pacific Southwest Forest and Range Experiment Station, pp. 149-161.

Theng, B.K.G. 1982. Clay-polymer interaction: Summary and perspectives. Clays and Clay Minerals 30, 1-10.

Vacher, C.A., Loch, R.J., Raiste, S.R. 2003. Effect of polyacrylamide additions on infiltration and erosion of disturbed lands. Australian Journal of Soil Research 41, 1509-1520.

Vega, J.A., Fernández, C., Pérez-Gorostiaga, P., Fonturbel, M.T. 2008. The influence of fire severity, serotiny, and post-fire management on Pinus pinaster Ait. recruitment in three burnt areas in Galicia (NW Spain). Forest Ecology and Management 256, 1596-1603. 
Verheijen, F.G.A., Jones, R.J.A., Rickson, R.J., Smith, C.J. 2009. Tolerable versus actual soil erosion rates in Europe. Earth-Science Reviews 94, 23-38.

Wagenbrenner, J.W., MacDonald, L.H., Rough, D. 2006. Effectiveness of three post-fire rehabilitation treatments in the Colorado Front Range. Hydrological Processes 20, 29893006.

Wakatsuki, T., Rasyidin, A. 1992. Rates of weathering and soil formation. Geoderma 52, 251-263.

Wallace, A., Wallace, G. 1986. Enhancement of the effect of coal fly ash by a polyacrylamide soil conditioner on growth of wheat. Soil Science 141(5), 387-389.

Wohlgemuth, P.M., Robichaud, P.R. 2007. The Effects of Selected Postfire Emergency Rehabilitation Techniques on Small Watershed. In Proceedings of the Forest Service National Earth Sciences Conference, San Diego, CA. GTR-689, pp 36-42.

Wohlgemuth, P.M., Beyers, J.L., Hubbert, K.R. 2009. Rehabilitation strategies after fire: the California, USA experience. In Fire effects on soils and restoration strategies, A. Cerdà, P. R. Robichaud (eds.), Science Publishers, Enfield, NH, USA, pp 511-535.

Wohlgemuth, P.M., Beyers J.L., Robichaud P.R. 2011. The Effectiveness of Aerial Hydromulch as an Erosion Control Treatment in Burned Chaparral Watersheds, Southern California. In The Fourth Interagency Conference on Research in the Watersheds, Fairbanks, AK.

Yanosek, K.A., Foltz, R.B., Dooley, J.H. 2006. Performance assessment of wood strand erosion control materials among varying slopes, soil textures and cover amounts. Journal of Soil and Water Conservation 61, 45-51. 